Ardeth
A magazine on the power of the project
III
$\quad \begin{aligned} & \mathbf{6} \mid \mathbf{2 0 2 0} \\ & \text { Contingency }\end{aligned}$

\title{
Design and the Challenge of Change
}

The Editorial Board of "Ardeth"

Francesca Frassoldati, Alessandro Armando, Daniele Campobenedetto, Valeria Federighi, Caterina Barioglio and Federico Cesareo

\section{(2) OpenEdition}

\section{Journals}

Electronic version

URL: http://journals.openedition.org/ardeth/1105

ISSN: 2611-934X

Publisher

Rosenberg \& Sellier

Printed version

Date of publication: 1 September 2020

Number of pages: 4-11

ISSN: 2532-6457

Electronic reference

Francesca Frassoldati, Alessandro Armando, Daniele Campobenedetto, Valeria Federighi, Caterina Barioglio and Federico Cesareo, "Design and the Challenge of Change", Ardeth [Online], 6 | 2020, Online since 01 November 2020, connection on 19 January 2021. URL: http://journals.openedition.org/ ardeth/1105 

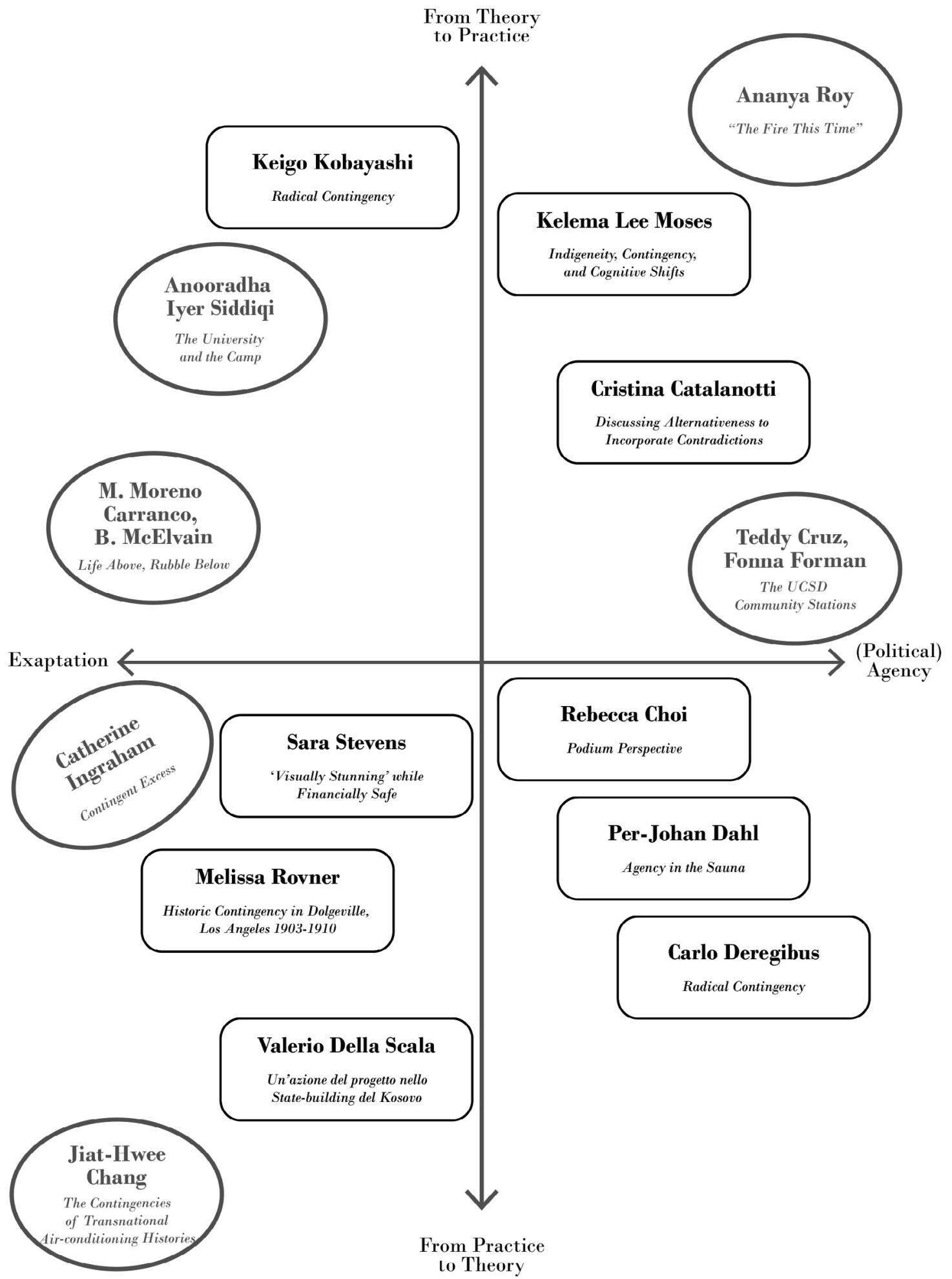

\section{Valerio Della Scala}

Un'azione del progetto nello State-building del Kosovo

Jiat-Hwee Chang

he Contingencie $f$ Transnational From Practice to Theory 


\section{Design and the Challenge of Change La sfida del progetto}

The Editorial Board of "Ardeth"

In the common acceptation of the term, contingency is the opposite of necessity and foreseeable regularity: it applies to a condition whereby someone (or something) find themselves acting in a singular situation, unique and unrepeatable in time and space. Contingency is where fortune happens to "contact/touch" (cum-tangere) the subject, in a manner that cannot in any way be subsumed under general laws. In Machiavelli, fortune/contingency is what lies outside the realm of politics and yet constitutes its core. Then, during the course of the 20th century, within the framework of the so-called political theology, contingency took on the role of key notion in a discourse centred on the discussion and deconstruction of the concept of sovereignty. In Carl Schmitt's essay Political Theology (1922), though it does not appear very often, the term "contingency" is used to define the original, indeterminate, chaotic conditions political decisions issue from. "Sovereign is he who decides on the exception”. As we are reminded by Carlo Galli: "The Schmittian decision is the 'performative act' that stops the flow of subjective discourse and in a (from a) contingency from the concrete poignancy of a kairòs - creates form"

Contacts: redazione [at] ardeth [dot] eu

DOI:

10.17454/ARDETH06.01

ARDETH\#06 
(Galli, 1996: 217). Yet, according to Schmitt, it is not so much contingency per se as it is the exception that - through a decision made in an emergency - makes the law into an absolute act: "The exception is that which cannot be subsumed; it defies general codification, but it simultaneously reveals a specifically juristic element - the decision in absolute purity. [...] The decision frees itself from all normative ties and becomes in the true sense absolute" (Schmitt, 1985: 12-13). Thus, according to Schmitt, it would seem possible to call on contingency to affirm the ineludible necessity of a decision, conceived as a sovereign act that addresses a state of exception. From this perspective, the legitimacy of the decision maker is absolute, it is not conditioned by external or higher criteria: one might say that a sovereign is legitimate in as much as they decide (not by virtue of how they decide) in the contingency of a "state of exception". Conversely, in Walter Benjamin we find a definition of contingency that is diametrically opposed to that of Schmitt, whereby each instant can be an exceptional one, where the revolution may find fertile ground: "The tradition of the oppressed teaches us that the 'emergency situation' (state of exception) in which we live is the rule. We must arrive at a concept of history that corresponds to this. Then it will become clear that the task before us is the introduction of a real state of emergency, and our position in the struggle against Fascism will thereby improve” (Benjamin, 2005). If this is so, the wait for a "true exception" announces the end, not the onset, of an established order. From Benjamin's viewpoint, the contingency becomes a trigger for the dismantling, the repudiation that preludes the coming of an ulterior state (the revolution accomplished?) and goes well beyond the mere arrogance of a dictator or any would-be sovereign power. Since his early writings of the 1920s, such as Critique of Violence, Benjamin has asserted that "the use of violence as a means towards legal ends" (Benjamin, 2004: 241) would only be an imperfect, "mythic" form of violence, as opposed to the "divine" form, i.e., the only violence truly capable of dismissing the established order. Nowadays, Giorgio Agamben's theses (2014) on "inoperosity" and the "destituent power" clearly reflect that theoretical background.

However, there is one aspect that seems to bridge the views of Schmitt and Benjamin: it is the fragmentary way they conceive time as a succession of states of exception or "splinters of messianic time". As pointed out by Carlo Galli (1996: 401): "It is this sensitivity to the extreme and the contingency that gives rise to a remarkable - albeit more apparent than real - analogy between Benjamin's now-time and Schmitt's 'exception', an analogy between two ways of conceiving history that converge if nothing else in rejecting its progressiveness". In this concept of time there seems to be no room for the process, its construction and incremental planning: everything is subsumed under the instant.

From these theological-political underpinnings - i.e., the relationship between contingency, decision and form, and a fragmentary concept of time - it is easy to draw a parallel with architectural design. If often 
happens that design work is regarded as an activity essentially founded on a series of autonomous and sovereign decisions, which are able to deal with "contingencies" and uncertainties. If you look closely, though, the misunderstanding and the problem with this "autonomistic" approach arises from a confusion between contingency and exception, or, more precisely, from the notion that every contingency constitutes an exceptional situation requiring a decisive action. But where does viewing design acts as potential cases of exception, in an open analogy to political theology, lead us to? First of all, it engenders a rift between what is exceptional and what is not. As a result, the designer's practice is polarised between sovereign decision-making moments and run-of-the-mill routine activities: the former would be a prerogative of star architects and the latter would be tasks best relegated to the rank of technical work, associated with a purely administrative "management paradigm”. In recent years, the main advocate of this position has been Pier Vittorio Aureli. In The possibility of an absolute architecture, Aureli (2011: 176) explicitly refers to Schmitt and his "theory of the state of exception" to justify the need for an "absolute architecture": "According to Schmitt, it is not the norm that eventually produces the exception; it is the exception that produces the order necessary to be able to conceive and apply norms. [...] the theory of the state of exception addresses the priority of decisions and their exceptional and conjunctural form in establishing a framework in which norms are thus applicable”.

In a discussion about architectural projects, though, we may address the issue from a different perspective and clearly distinguish between contingency and exception: even if it were true that Schmitt was right in regarding a case of exception as a pure contingency, this does not mean that all contingencies are exceptional. Conversely, it could be argued that the opposite is true, i.e., most contingent situations are perfectly ordinary and provide the stage where design actions unfold. In this light, the architectural project may be conceived as a practice involving an incessant overcoming of contingencies, of situations, that is, where the prevailing activity does not consist of decisions being made by subjects ideally conceived as sovereign, but consists instead of a mesh of automatic procedures, negotiations, promises, deviations. Thus, rather than as a sequence of sovereign gestures, a designer's activity may be described as a slow and painstaking sequence of knots that are unravelled and knotted again and again, many times, one inside the other and one after the other.

Between a state of exception and another, there is room for creating design projects that are neither exceptional nor ordinary. Architects mostly work in the shadow of these institutional constructions, which continue to exist, their contradictions and approximations notwithstanding, and rely on conditions, rules and routines to oppose the independence of form and narrative. 
Needless to say, the discussion is open: what relationship do we want the relationship between decision and contingency in architectural design projects to be like? Do we want to consider architects sovereign and responsible subjects who come to grips with contingencies on the basis of their intentionality and determination, or should we rather view contingency as a situation to go along with, from which unforeseeable opportunity may arise? (a more intuitive version of this dilemma was cited in recent years by François Jullien, who reproposed André G. Haudricourt’s contraposition between "shepherds" and "gardeners"). But the discussion should include yet another question: what does it mean to have a method in the face of contingency? Is it possible to establish recurring conditions for design work, or should we always pay undivided attention to the singularity of the situations?

The question formulated in this issue of “Ardeth" by Dana Cuff and Will Davis has received a number of highly diversified replies. To try and organise the differences between the positions expressed, we considered the two aforementioned dimensions: a markedly political and a methodological one. Thus, on the horizontal axis we have arranged the contrast between ordinary contingency and exceptional contingency, between the approach that finds in contingency designs opportunities - in terms of “ex-aptation”, to cite S. J. Gould, as well as ordinary practice and negotiation opportunities - and, at the opposite end of the spectrum, the resolute will to single out the contingency, construed as a suspension and an exception onto which a form may be imposed - in terms of policy, of an exemplary vision for the future, or in terms of projects-programmatic measures.

Along the vertical axis, instead, we have placed the issues to do with a methodical and a contingent modus operandi. At the upper end, we have the "method", conceived as a limit approach whereby from a general definition (a theory?) it is possible to derive the appropriate way to act in a contingency. At the bottom end, instead, we have the "operation", i.e., an approach whereby the contingent action escapes any generalisation. In this manner we obtained four quadrants in which to distribute the author's contributions.

The first quadrant identifies the manifestos, that is to say, the ideas drawing inspiration from methodical deduction and decisive political agentivity. In the essay by Rebecca Choi, the charismatic figure of Whitney M. Young Jr. identifies the ethnic contingency (the "racial contingency") apparent in public residential buildings in US cities as the outcome of centuries of segregationist policies and social structures, at different levels of explicitation. Taking as its starting point a public speech delivered at the conference of the American Institute of Architects two weeks after the death of Martin Luther King Jr., the essay underscores the (retroactive) urgency to acknowledge the awareness of the social impact of a design project. Kelema Lee Moses believes that the contingency of contemporaneity should be mediated by local voices, so as to produce an 
interpretative stratification that can decentralise western epistemologies and architectural practices, and can also capture that complex systems of interaction between physical space and social space. According to Teddy Cruz and Fonna Forman, an architectural project gives expression to participation models and pedagogical theories, and contingency is taken into due account for purposes of inclusivity and transformation. Starting from similar premises, Cristina Catalanotti argues that in the contingency the project determines the field of action of the professionals who attempt to define "alternative" practice models in contrast with a perceived mainstream of the profession. The author analyses the position of a number of emerging design studios that work outside the socio-economic models reflecting the ideology of neoliberalism and do so through collective actions that are part of real processes and that, instead of addressing singular problems, raise questions and achieve enhanced political significance. Ananya Roy focuses on the importance of understanding urban transformation through minority settlement and mobilisation stories. The ruling out of particular contingency regimes translates into an act of discrimination against the weaker sections of society and calls into question their right to the city. In this understanding, the contingency becomes the necessary condition for any ethical action. Finally, Carlo Deregibus points out how the relationship between design practice and contingency tends to go unnoticed in the narratives of successful design processes, but emerges with clarity in the case of unsuccessful ones. Reversing the paradigm, the author underscores the potential of contingency and proposes contingency mapping as a means to bring out the specificity of a project and at the same time strike the best balance between the resources available and the objectives to be met.

The second quadrant is reserved for exemplary cases, i.e., for essays that focus on practice, putting their trust in the decisive efficacy of political agentivity. This is the field of induction - from operations (or from experiences) to a method -, bringing together the decisionist tendency of political agentivity (faith in the power of good decisions) and the contingent, non programmable actions required by ever different cases. In this quadrant, the essay by Sara Stevens investigates the relationship between the design process and the forces of capitalism. In her study of the troubled process of urban renewal of Canary Wharf, the effects of financialisation and political changes exemplify a design approach that would eventually become the rule for architects, in terms of the way they organise their design practice and how they pursue the production of visually stunning objects. In this connection, the organisation of the architects' mode of operation is not adaptive, it is politically instrumental to the new-fangled (high risk) financial practices. In his considerations, Per-Johan Dahl also adopts the horizon of events developing over time. The case of the participated construction of the sauna facilities in Frihamnen - which, once built (as a provisional structure) and functioning, were defended as a monument to be preserved - shows how tactic resort to community 
participation may become the prototype of a potentially overwhelming form of public decision-making, where the contingency is a condition to be dealt with on a daily basis.

The third quadrant is for clinical cases. Here the pieces move between the field of induction and the field of emergency agentivity, conceived as the operation of an agent who addresses the contingency as an accident along a predetermined path, and takes action and adapts to the occurrence of an emergency. Catherine Ingraham, whose essay opens the issue by reacting directly to the inputs of the curators, reflects on the dimension of "contingent excess" in architecture. By calling into question the notion of excess as a mere product of capitalistic consumption patterns (surplus) and proposing a view of this excess as the dimension of the project acting within the boundaries of the legal systems and property regimes, Ingraham identifies the field through it is possible to address the effects of the architectural project even beyond its physical realisation. In her essay, Melissa Rovner explores the case of Dolgeville and the changes that took place in this district of Los Angeles during the course of the first half of the 20th century, pointing out the connections between the design of physical space and its role in the contingency of the changing economic and social context that contributed to its definition Jiat-Hwee Chang focuses on the scale of buildings and explores the contingency of the use of HVAC systems in Asia. The construct of the concept of thermal comfort is put in correlation with social and cultural variables, and architecture is conceived as a mechanism called upon to achieve increasingly standardised temperature control requirements. Finally, Valerio Della Scala proposes an analysis of The Yellow Pavilion, an installation erected in the city of Pristina: taking his cue from this case, the author proposes identifying the forms of action that can affect not only physical space, but also the normative conditions that generate it and their reference framework.

The last quadrant delimits an area that might be referred to as the realm of strategies, i.e., of the approaches that attempt to define a general mode (a method?) to address the contingent dimensions of the project, without however proposing any affirmative solution. In these essays, as a matter of fact, the project systematically strives to achieve the necessary plasticity to adhere to the contingencies of the ordinary.

The first two essays are linked by an event, the workshop "Inside-Out/ Outside-In: Shifting Architectures of Refugee Inhabitation" held in January 2019 at the Max Planck Institute for the Study of Religious \& Ethnic Diversity in Göttingen. The organisers of the event, Somayeh Chitchian, Maja Momic and Shahd Seethaler-Wari, propose a summary focusing on the notion of contingency referred both to the "subjects" and to the "spaces". The "inhabitation of an otherwise" is an ordinary, invariably contingent, process. It is claimed that at the heart of this process are the inhabitants and their contingent competencies, which cannot be replaced by expert, external know-how: "Inhabitation, in essence, is a contingent 
process of spatial authorship and (re)production, a yet-to-come design of the unlabelled architect, a yet-to-be-written spatial story of its invisibilised author".

Along similar lines, but through stories (and their contingencies), runs the essay submitted by Anooradha Iyer Siddiqi - keynote speaker at the same workshop. The author dwells on the parallel between research objects that all too often are considered separately, or even in contraposition, such as refugee camps and university campuses: "What if the inhabitation of the camp generated theory, practices, and ritual knowledge of its own?" In this case too, it is the parallel between the subjects-inhabitants (and their impermanence) and that of the space inhabited (its lack of foundations and provisional nature) that produces a deviation through which theoretical research on the design project may find a locus for development.

Nel senso comune, intendiamo di solito la contingenza come l'opposto della necessità e della regolarità prevedibile, tale per cui qualcuno (o qualcosa) si trova ad agire in una situazione singolare, unica e irripetibile nel tempo e nello spazio. La contingenza è il punto in cui la fortuna tocca (cum-tangere) il soggetto, in modo del tutto irriducibile a delle leggi generali. In Machiavelli la fortuna-contingenza è ciò che si situa al di fuori della politica, e che al tempo stesso ne costituisce il fulcro. Lungo il Novecento, nell'ambito della cosiddetta teologia politica, la contingenza è stata poi assunta a nozione chiave di un discorso incentrato sulla discussione e decostruzione del concetto di sovranità. Nel saggio di Carl Schmitt Teologia politica (1922) il termine "contingenza”, pur non ricorrendo molto spesso, viene utilizzato per definire la condizione originaria, informe e disordinata, entro cui si genera la decisione politica. "Sovrano è chi decide sullo stato di eccezione": Come ci ricorda Carlo Galli, "la decisione schmittiana è l'atto performativo' che interrompe il fluire del discorso soggettivo e che nella (e dalla) contingenza - dalla puntualità concreta di un kairòs - crea forma" (Galli, 1996: 217). Per Schmitt peraltro non è tanto la contingenza in sé, quanto l'eccezione a costituire l'elemento primario per porre il diritto, attraverso la decisione, come atto assoluto: "L'eccezione è ciò che non è riconducibile; essa si sottrae all'ipotesi generale, ma nello stesso tempo rende palese in assoluta purezza un elemento formale specificamente giuridico: la decisione. [...] La decisione si rende libera da ogni vincolo normativo e diventa assoluta in senso proprio" (Schmitt, 1972: 39). Seguendo Schmitt, sembrerebbe quindi possibile appellarsi alla contingenza per rivendicare la necessità ineludibile di una decisione, intesa come atto sovrano che risolve uno stato di eccezione. In questa prospettiva la legittimità del decisore è assoluta, non risponde a principi o criteri esterni e superiori: si potrebbe dire che il sovrano è legittimo in quanto decide (e non in base a come decide) nella contingenza di uno "stato di eccezione". 
Viceversa, in Walter Benjamin leggiamo una definizione di contingenza diametralmente opposta a quella di Schmitt, secondo la quale ogni istante può essere un istante eccezionale, dove si può incuneare la rivoluzione: "La tradizione degli oppressi ci insegna che lo «stato d'eccezione» in cui viviamo è la regola. Dobbiamo giungere a un concetto di storia che corrisponda a questo. Allora ci starà davanti, come nostro compito, di suscitare il vero stato d'eccezione, migliorando così la nostra posizione nella lotta contro il fascismo" (Benjamin, 1997: 33). In questo caso l'attesa di una "vera eccezione" corrisponde alla fine di un ordine, non al suo inizio. Nella prospettiva di Benjamin la contingenza diviene l'occasione dello smantellamento, della dismissione, che prelude alla venuta di uno stato ulteriore (la rivoluzione compiuta?), e che si pone al di là della mera prepotenza di un dittatore, o di un qualsiasi sedicente decisore sovrano. Per Benjamin (già dagli scritti degli anni Venti, come Per una critica della violenza) "l'impiego della violenza come mezzo a fini giuridici" (Benjamin, 2008: 473) sarebbe soltanto una forma imperfetta, "mitica” rispetto a quella “divina”, l'unica capace di una vera destituzione dell'ordine costituito. Oggi, le tesi di Giorgio Agamben (2014) sulla "inoperosità” e il "potere destituente" rispecchiano dichiaratamente quello sfondo teorico. C'è però un aspetto che sembra legare le posizioni di Schmitt e Benjamin, ed è il modo frammentario di concepire il tempo, come successione di stati di eccezione o di "schegge del tempo messianico". Come nota sempre Carlo Galli (1996: 401): "È questa sensibilità per l'estremo e per la contingenza a determinare una analogia vistosa - ma più apparente che realefra il 'tempo-ora' di Benjamin e l'eccezione' di Schmitt, un'analogia fra due modi di pensare la storia che convergono almeno nel rifiutarne la progressività". In questa concezione della temporalità non sembra esserci spazio per il processo, la sua costruzione e progettazione incrementale: tutto è ricondotto all'istante.

Da questi presupposti teologico politici - ovvero il rapporto tra contingenza, decisione e forma, e una concezione del tempo a frammenti - è possibile derivare dei paralleli con la progettazione architettonica. Non è infrequente che il lavoro di progetto venga inteso come attività sostanzialmente fondata su una serie di decisioni autonome e sovrane, capaci di risolvere le "contingenze" e le incertezze. A ben vedere, il problema e il malinteso di questo approccio "autonomista" si basa sulla confusione tra contingenza ed eccezione, o meglio, sull'idea che ogni contingenza costituisca una situazione eccezionale che richiede un atto decisivo. Ma a cosa conduce il fatto di considerare gli atti di progetto come possibili casi di eccezione, in aperta analogia con la teologia politica? Innanzitutto genera una spaccatura, tra ciò che è eccezionale e ciò che non lo è. Di conseguenza la pratica del progettista viene polarizzata tra gli istanti di decisione sovrana e le routine di amministrazione ordinaria: i primi sarebbero appannaggio degli architetti-autori, le seconde sarebbero delegabili al puro lavoro tecnico, poiché riconducibili a un "paradigma gestionale” di mera amministrazione. Il principale sostenitore di questa 
posizione, in anni recenti, è stato Pier Vittorio Aureli. Nel suo testo The possibility of an absolute architecture Aureli (2011: 176) richiama esplicitamente Schmitt e la "teoria dello stato di eccezione” per giustificare la necessità di una "architettura assoluta": "According to Schmitt, it is not the norm that eventually produces the exception; it is the exception that produces the order necessary to be able to conceive and apply norms. [...] the theory of the state of exception addresses the priority of decisions and their exceptional and conjunctural form in establishing a framework in which norms are thus applicable”.

Parlando di progetti di architettura, possiamo però anche assumere un atteggiamento diverso, distinguendo chiaramente la contingenza dall'eccezione: se pure Schmitt avesse avuto ragione nel considerare il caso di eccezione come pura contingenza, ciò non significa affatto che tutte le contingenze siano eccezionali. Anzi: potremmo sostenere proprio il contrario, ovvero che la maggior parte delle situazioni contingenti siano del tutto ordinarie, e costituiscano il tessuto entro cui si dipanano le azioni di progetto. Il progetto di architettura può, in questo senso, essere inteso come una pratica di attraversamento continuo di contingenze, ovvero di situazioni in cui l'attività prevalente non è la decisione di soggetti che si vorrebbero sovrani, bensì l'intreccio di procedure automatiche, negoziazioni, promesse, deviazioni. Piuttosto che una sequenza di gesti sovrani, l'attività progettisti potrebbe dunque essere descritta come una lenta e paziente sequenza di nodi, che vengono sciolti e riannodati molte volte, uno dentro l'altro e uno dopo l'altro.

Tra uno stato di eccezione e l'altro si apre la possibilità di fare dei progetti - né eccezionali, né ordinari. La pratica degli architetti si svolge soprattutto all'ombra di queste costruzioni istituzionali, che continuano a esistere, malgrado le loro contraddizioni e approssimazioni, e che danno consistenza concreta ai progetti opponendo condizioni, regole e routines all'autonomia della forma e delle narrazioni.

Naturalmente, la discussione è aperta: che rapporto vogliamo porre tra decisione e contingenza nei progetti di architettura? Vogliamo considerare gli architetti come dei soggetti sovrani e responsabili che sfidano le contingenze sulla base della loro intenzionalità e volontà determinante, oppure assumiamo la contingenza come una situazione da assecondare, da cui possono emergere delle opportunità imprevedibili? (una versione più intuitiva di questo dilemma è stata richiamata in anni recenti da François Jullien, nel riproporre la contrapposizione tra "pastori” e "giardinieri” di André G. Haudricourt). Ma la discussione deve riguardare anche una seconda domanda: che cosa significa avere un metodo di fronte alla contingenza? È possibile stabilire delle condizioni ricorsive del lavoro di progetto o dobbiamo affidarci radicalmente, ogni volta, alla singolarità delle situazioni?

La questione posta in questo numero di “Ardeth” da Dana Cuff e Will Davis ha ricevuto un insieme di risposte molto diversificate. Per tentare di ordinare le differenze tra queste posizioni, abbiamo considerato le 
due dimensioni della contingenza appena nominate: una più marcatamente politica, l'altra metodologica. Così sull'asse orizzontale abbiamo tentato di disporre l'opposizione tra contingenza ordinaria e contingenza eccezionale, tra un atteggiamento che deduce occasioni di progetto dalla contingenza - in termini di "ex-aptation" per citare S. J. Gould, ma anche di pratica ordinaria e di negoziazione - e, al limite opposto, di una volontà di determinazione della contingenza, intesa invece come sospensione ed eccezione a cui è possibile imporre una forma - in termini di policy, di visione esemplare per il futuro o di progetto-provvedimento.

Sull'asse verticale abbiamo invece disposto la questione dell'agire metodico e contingente. All'estremo superiore si trova il "metodo", inteso come atteggiamento-limite secondo cui è possibile dedurre da definizioni generali (una teoria?) le giuste modalità di azione nella contingenza. All'estremo inferiore abbiamo posto invece l'“operazione”, ovvero l'atteggiamento che considera l'azione contingente irriducibile a qualsiasi generalizzazione. Ne sono derivati pertanto quattro quadranti, in cui si dispongono i discorsi degli autori.

Il primo quadrante identifica i manifesti, ossia i pezzi che si muovono fra la deduzione metodica e l'agentività politica determinante. Nel saggio di Rebecca Choi, la figura carismatica di Whitney M. Young Jr. rivela la contingenza etnica ("racial contingency") evidente negli edifici residenziali pubblici delle città statunitensi come il risultato di secoli di politiche e strutture sociali segregazioniste, a vari livelli di esplicitazione. Prendendo come punto di partenza un discorso pubblico fatto al congresso dell'American Institute of Architects due settimane dopo la morte di Martin Luther King Jr., il saggio rivendica l'urgenza (retroattiva) di discutere la consapevolezza dell'impatto sociale del progetto. Kelema Lee Moses chiede che la contingenza della contemporaneità sia mediata da voci locali, producendo una stratificazione interpretativa capace di decentralizzare le epistemologie e le pratiche d'architettura occidentali e capace altresì di cogliere i complessi sistemi di relazioni tra spazio fisico e sociale. Per Teddy Cruz e Fonna Forman il progetto di architettura è un progetto di modelli di partecipazione e pedagogie, che tiene dentro la contingenza in vista di un obiettivo di inclusività e trasformazione. Partendo da premesse simili, per Cristina Catalanotti il progetto nella contingenza definisce il campo di azione dei professionisti che tentano di definire modelli di pratica "alternativa" rispetto a un percepito "mainstream” della professione. L’autrice analizza la posizione di un numero di pratiche emergenti che agiscono al di fuori di modelli socio-economici di derivazione neoliberista, attraverso azioni collettive che si inseriscono in processi reali e, invece che tentare di risolvere specifici problemi, sollevano questioni e ne aumentano la portata politica. Ananya Roy sostiene l'importanza di comprendere le trasformazioni urbane attraverso le storie di insediamento e di mobilitazione di minoranze. La messa al bando di particolari regimi di contingenza si traduce in un atto discriminatorio nei confronti dei ceti più deboli che mette in dubbio il loro diritto 
alla città. In questa prospettiva, la contingenza diventa il presupposto per qualsivoglia azione etica. Infine, Carlo Deregibus osserva come la relazione tra pratica progettuale e contingenza tenda a essere nascosta nelle produzioni narrative di processi progettuali di successo, mentre emerga con chiarezza da quelle di insuccesso. Ribaltando il paradigma, l'autore sottolinea il potenziale della contingenza e ne propone una mappatura per far emergere la specificità del progetto e farne oscillare il processo tra mezzi disponibili e finalità programmate.

Il secondo quadrante definisce i casi esemplari, intesi come gli scritti che partono dalla pratica confidando nell'efficacia determinante dell'agentività politica. È il campo dell'induzione dalle operazioni (o esperienze) al metodo, che tiene insieme la tendenza direttiva dell'agentività politica (la fiducia nel potere delle buone decisioni) con l'azione contingente, non programmabile dei casi sempre diversi. In questo quadrante, il saggio di Sara Stevens indaga le azioni di progetto rispetto alle forze del capitalismo. Nel suo studio sull'accidentato processo di trasformazione di Canary Wharf, gli effetti della finanziarizzazione e dei cambiamenti nel panorama politico diventano esemplari di un modo successivamente diventato regola di progetto per gli architetti, sia in termini di organizzazione della pratica progettuale, sia nel senso di perseguire la produzione di oggetti “visually stunning”. L'organizzazione dell'agire dei progettisti, in questo senso, non è adattivo ma politicamente strumentale alle nuove pratiche finanziarie (del rischio). Anche la riflessione di Per-Johan Dahl assume l'orizzonte di una sezione attraverso il tempo. Il caso della costruzione partecipata della sauna a Frihamnen - che una volta realizzata (come oggetto temporaneo) ed entrata in uso viene difesa come monumento da preservare - mostra come l'episodicità tattica della partecipazione possa diventare il prototipo di una forma potenzialmente dirompente di decisione pubblica, dove la contingenza viene assunta come condizione quotidiana.

Il terzo quadrante è quello dei casi clinici. Qui, i pezzi si muovono fra il campo dell'induzione e il campo dell'agentività emergenziale, intesa come il movimento di un agente che assume la contingenza come accidente su un percorso tracciato, che agisce e si adatta all'occorrere dell'emergenza. Catherine Ingraham, il cui saggio apre il numero reagendo direttamente agli stimoli dei curatori, riflette sulla dimensione di “eccesso contingente” dell'architettura. Mettendo in discussione la nozione di eccesso come mero prodotto del consumo capitalistico (ecceden$z a$ ), e proponendo una visione di questo eccesso come la dimensione del progetto che agisce nel campo dei sistemi legali e dei regimi di proprietà, Ingraham identifica il campo attraverso il quale è possibile affrontare gli effetti del progetto di architettura andando oltre la sua realizzazione materiale. Il saggio di Melissa Rovner indaga il caso di Dolgeville e le trasformazioni di questo sobborgo di Los Angeles nella prima metà del $\mathrm{XX}$ secolo, mettendo in luce l'intreccio tra il progetto dello spazio fisico e il suo ruolo nella contingenza del mutevole contesto economico e sociale 
che contribuiva alla sua produzione. Jiat-Hwee Chang esplora la scala dell'edificio e restituisce la contingenza degli usi dei sistemi per l'aria condizionata in Asia. La costruzione del concetto di comfort termico è qui vista in relazione con le variabili sociali e culturali e l'architettura come un dispositivo chiamato a rispondere a condizioni di controllo della temperatura sempre più standardizzate. Infine, Valerio Della Scala propone un'analisi dell'installazione The Yellow Pavilion, realizzata nella città di Pristina. Attraverso questo caso l'autore propone di indagare le forme d'azione capaci di incidere non solo sullo spazio materiale, ma anche sulle condizioni normative che lo generano e sul loro quadro di riferimento.

L'ultimo quadrante delimita un ambito che potremmo definire il luogo delle strategie, ovvero di quegli approcci che tentano di definire un modo generale (un metodo?) di affrontare le dimensioni contingenti del progetto, senza per questo proporre soluzioni affermative. Piuttosto, in questi saggi il progetto tenta di assumere sistematicamente la plasticità necessaria per aderire alle contingenze dell'ordinario.

I primi due testi sono legati tra loro da un evento, il workshop "Inside-Out / Outside-In: Shifting Architectures of Refugee Inhabitation”, tenutosi nel gennaio 2019 al Max Planck Institute for the Study of Religious \& Ethnic Diversity di Gottinga. Gli organizzatori dell'evento, Somayeh Chitchian, Maja Momic e Shahd Seethaler-Wari, propongono una ricapitolazione che insiste soprattutto sulla nozione di contingenza riferita tanto ai "soggetti” quanto agli "spazi”. L'“abitare un altrimenti” ("inhabitation of an otherwise") è un processo ordinario, e sempre contingente. Al centro di questo processo ci sarebbero gli abitanti e la loro competenza contingente, irriducibile ad un sapere esperto ed esterno: "La pratica dell'abitare, in sostanza, è un processo contingente di definizione autoriale dello spazio e di (ri)produzione, un progetto a-venire dell'architetto senza titolo (anonimo?), una storia spazializzata del suo autore invisibile, ancora tutta da scrivere" ["Inhabitation, in essence, is a contingent process of spatial authorship and (re)production, a yet-to-come design of the unlabeled architect, a yet-to-be-written spatial story of its invisibilized author"].

Sullo stesso fronte, ma attraversando alcune storie (e la loro contingenza) si muove l'intervento di Anooradha Iyer Siddiqi - keynote lecture presso quello stesso workshop. Qui l'autore insiste sul parallelo tra oggetti di ricerca troppo spesso tenuti separati, se non in opposizione, come i campi di rifugiati e i campus universitari: “Cosa succederebbe se l'abitare il campo generasse una teoria, delle pratiche o dei rituali di conoscenza per proprio conto?" ["what if the inhabitation of the camp generated theory, practices, and ritual knowledge of its own?”] Anche in questo caso, è il parallelo tra la contingenza dei soggetti-abitanti (la loro impermanenza) e degli spazi abitati (la loro infondatezza e transitorietà) che produce uno scarto entro cui la ricerca teorica sul progetto può trovare un varco di sviluppo. 


\section{References}

Agamben, G. (2014), L'uso dei corpi: Homo sacer, IV, 2, Vicenza, Neri Pozza.

Aureli, P. V. (2011), The possibility of an absolute architecture, Cambridge (MA), The MIT Press.

Benjamin, W. (1997), Sul concetto di storia, Torino, Einaudi.

Benjamin, W. (2004 [1921]), Critique of Violence, in M. Bullock, M. Jennings (eds), Walter Benjamin: Selected Writings 1913-1926, Vol. 1, Cambridge-London, The

Belknap Press of Harvard University Press.

Benjamin, W. (2005 [1974]), Gesammelten Schriften I:2, trans. D. Redmond, Frankfurt am Main, Suhrkamp. Available at: https://bit.ly/39knqtp [Accessed: 22 July 2020].

Benjamin, W. (2008 [1921]), Per una critica della violenza, in Id., Opere complete. Scritti 1906-1922. Vol. 1, Torino, Einaudi.

Galli, C. (1996), Genealogia della politica. Carl Schmitt e la crisi del pensiero politico moderno, Bologna, il Mulino.

Schmitt, C. (1972 [1922]), Teologia politica. Quattro capitoli sulla dottrina della sovranità, in Id., Le categorie del "politico". Saggi di teoria politica, Bologna, il Mulino.

Schmitt, C. (1985 [1922]), Political Theology. Four Chapters on the Concept of Sovereignty, Cambridge (MA) - London, The MIT Press. 